\title{
Determination of the Occlusion Plane by the Piezographic Technique
}

\section{Chraief $\mathrm{H}^{*}$}

University of Monastir; faculty of dental medecine; oral health and oro-facial rehabilitation laboratory research; LR12ES11; 5000; Monastir; Tunisia

Submission: September 18, 2020; Published: September 25, 2020

*Corresponding author: Houda Chraief; University of Monastir; faculty of dental medecine; oral health and oro-facial rehabilitation laboratory research; LR12ES11; 5000; Monastir; Tunisia

\section{Summary}

The production of complete dentures is very common in dental practice, due to the increase in the number of edentulous people. The success of a prosthesis depends essentially on its acceptance by the patient and conditioned by the success of the aesthetic challenge. The occlusion plane should no longer meet standard criteria but be personalized using the piezographic technique.

Keywords: Piezography; Short upper lip; Occlusion plane

\section{Introduction}

The psychological integration of the complete denture is generally guaranteed when the patient is satisfied with the aesthetic result of his prosthesis. Aesthetic success is linked among other things to the situation of the anterior occlusion plane; if the patient has a short upper lip, the piezographic technique is recommended because the classic technique does not offer a satisfactory aesthetic result.

\section{Presentation of the Clinical Case}

This is a 71-year-old patient that is consulting for complete prosthetic rehabilitation for aesthetic reasons. The patient has a short upper lip (Figure 1), which is why we opted for the piezographic technique. The technique consists at first in making a pink wax bead ton embody the occlusion plane that is parallel to the bi-pupillary line while protruding by $2 \mathrm{~mm}$ the upper lip at rest (Figure 2). Secondly, it involves eliminating half of the thickness of the bead at the level of the sector going from canine to canine (Figure 3), this is performed to create space to place the piezographic material (silicone without catalyst). We must also reduce the thickness of the base at the expense of its upper surface always at the level of the region from canine to canine (Figure 4). The patient is then invited to pronounce the phonemes B, P, M several times, thus obtaining a modeling of the piezographic material by the muscles of the upper lip: we obtain the piezogram, the deepest part of the imprint of these muscles corresponds to the anterior piezographic occlusion plane. We then cut out the material exceeding the anterior occlusion plane then we make a key into the vestibular plaster and then we transform the piezographic material into resin (we take the precaution by coloring it to be able to distinguish it from the base resin) [15]. The antero-superior teeth will be assembled using the key and will locate each tooth in the vestibulo-lingual and occlusal direction inside the space occupied by the piezogram (Figure 5). The other stages of prosthetic production are identical to that of the conventional technique. The advantage of this technique is essentially the aesthetic result (Figure 6).

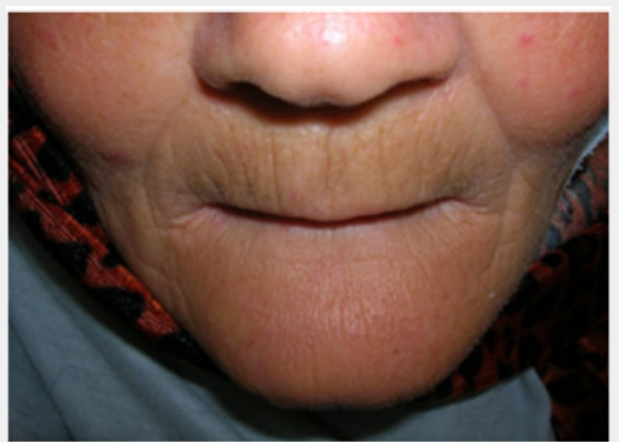

Figure 1: Teety 


\section{Advances in Dentistry \& Oral Health}

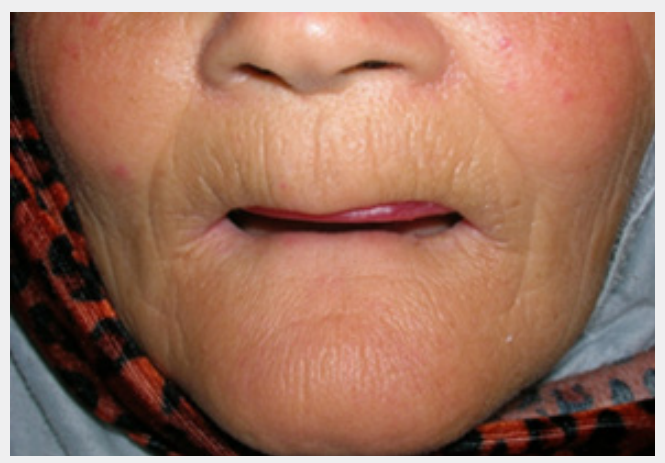

Figure 2: Adjustment of the anterior occlusion plane (classical technique).

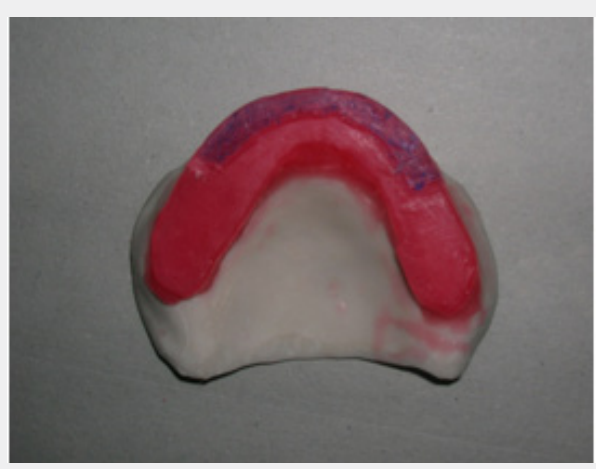

Figure 3: Recess of the anterior sector of the occlusion rim

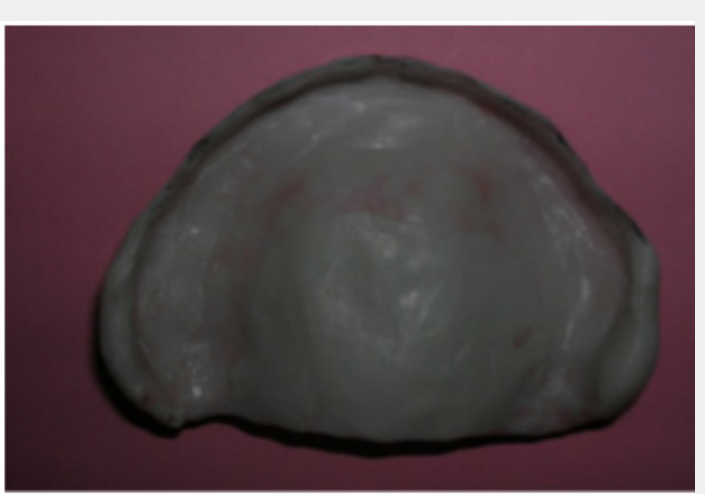

Figure 4: Minimum thickness of the occlusion base.

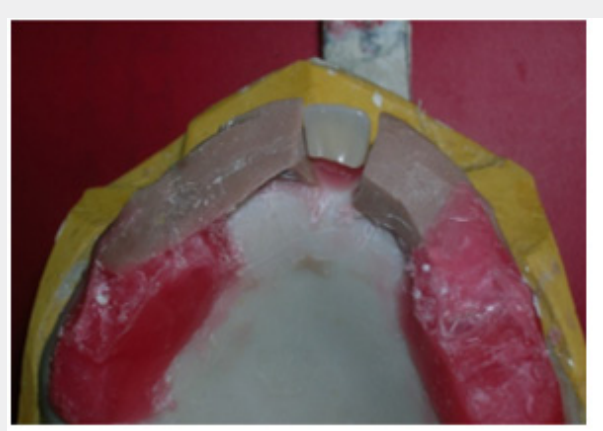

(a)

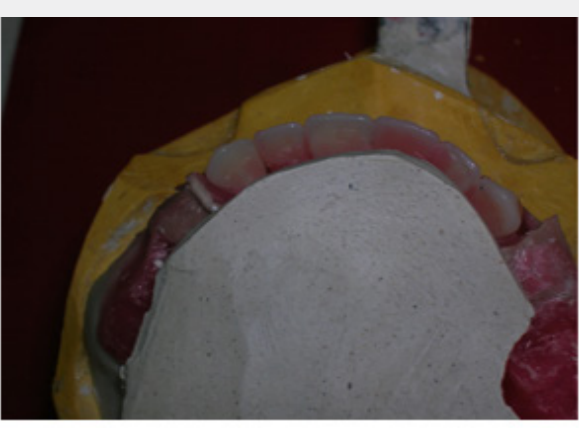

(b)

Figure 5a,b: The central incisor mounted; The six anterior teeth mounted. 

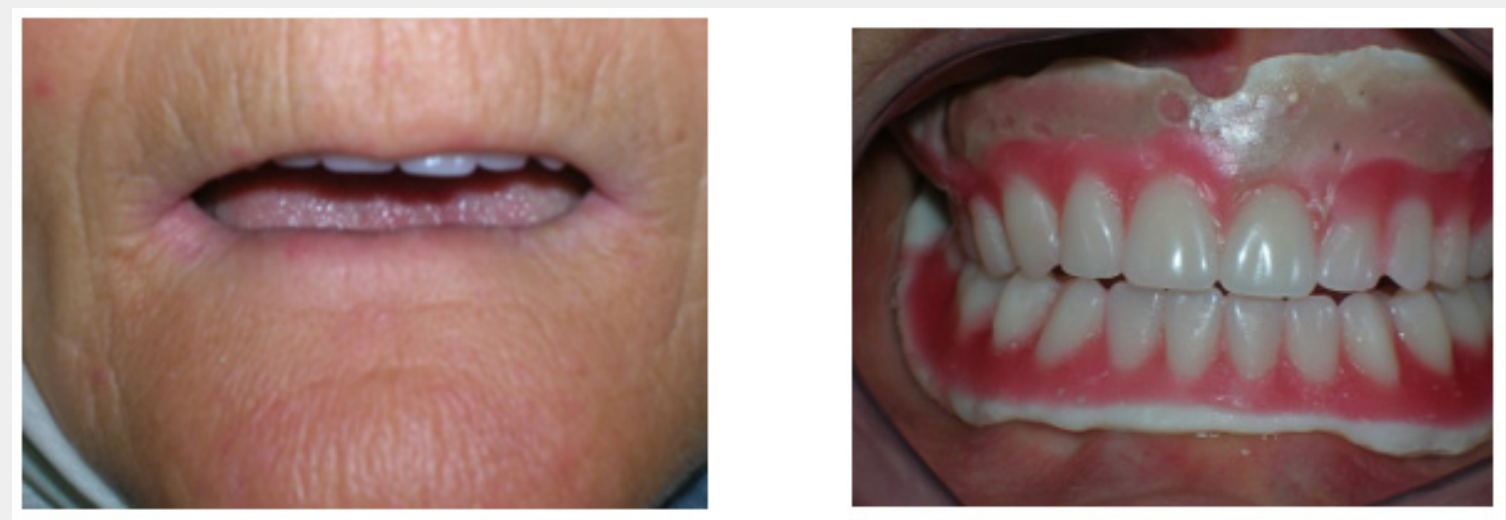

Figure 6: The aesthetic result.

\section{Conclusion}

The use of the piezographic technique in complete prosthesis reinforce clinician's appropriate response to his patient's physiology as good as possible; it also allows the teeth to be mounted in a position which respects both the muscular environment, the DVO, the orientation of the occlusion plane as well as aesthetic requirements.

\section{References}

1. Klein P. Prothèse piézographique prothèse adjointe totale gériatrique.
2. Nabid A (1996) Piézologie. Applications cliniques. Encycl Méd. Chir, stomatologie-odontologie.

3. Lombardi Re (1973) The principles of visual perception and their clinical application to dentures esthetics. J Prothet Dent 29(4): 358382.

4. Bernhardt M (2001) Piézographie et plan d'occlsion en prothèse adjointe totale, Synergie prothétique 3(2).

5. La prothèse piézographique, Mémoire de fin d'étude pour l'obtention du diplôme de Docteur en Médecine Dentaire, Benyettou.

\section{Your next submission with Juniper Publishers} will reach you the below assets

- Quality Editorial service

- Swift Peer Review

- Reprints availability

- E-prints Service

- Manuscript Podcast for convenient understanding

- Global attainment for your research

- Manuscript accessibility in different formats ( Pdf, E-pub, Full Text, Audio)

- Unceasing customer service

Track the below URL for one-step submission https://juniperpublishers.com/online-submission.php 